\title{
Experimental Investigation of Soil Behaviour Using Industrial Fly Ash
}

\author{
Sonu Prasad \\ Civil Engineering Department, Kalinga University, Raipur, Chhattisgarh, India \\ Email address: \\ sonu.prasad@kalingauniversity.ac.in

\section{To cite this article:} \\ Sonu Prasad. Experimental Investigation of Soil Behaviour Using Industrial Fly Ash. American Journal of Engineering and Technology \\ Management. Vol. 6, No. 2, 2021, pp. 24-27. doi: 10.11648/j.ajetm.20210602.12
}

Received: November 24, 2020; Accepted: March 17, 2021; Published: May 20, 2021

\begin{abstract}
All the infrastructure projects such as buildings, railways, water reservoirs etc. require earth materials in a large quantity. In urban areas most of the soil are of highly plastic and expanse which is not suitable for all purpose. Many times we need to haul the suitable soil from a large distance which is not economical. The behavior of soil varies with different agencies like water, temperature, and region of soil, other atmospheric agencies, and mixed surplus material also. In this project we will be tried to established important properties of soil by using fly ash which is an industrial waste material, Fly ash causes various environmental problems like groundwater contaminants. So utilizing fly ash in soil stabilization can minimize such environmental hazards. In this project we will perform direct shear test, California bearing ratio (CBR) test, unconfined compression test and proctor compaction test. For this project we selected Black cotton soil which is available in Near Mantralaya, Naya Raipur (Chhattisgarh) India, region. We followed all the procedure prescribed in IS 2720 Part 7, 10, 16, and 40. Fly ash is often wont to stabilization bases or sub grade to stabilize back fill to scale back lateral earth pressure and to stabilize embankments to boost slope stability. Typical stabilized soil depths are 15 to $46 \mathrm{~cm}$. the first reason ash is employed in soil stabilization applications is to boost the compressive and cutting strength of soils. The compressive strength of ash treated soils relies on-(i) in situ soil properties; (ii) Delay time; (iii) Moisture content at time of compaction; (iv) fly ash addition magnitude relation.
\end{abstract}

Keywords: Stability Analysis of Soil, Laboratory Test, Difference Between Original State of the Soil, Mixing Surplus Material (Fly Ash)

\section{Introduction}

Soil may change in its volume with changes in water content, which is the reason for damages and structure failure. Particularly for heavy construction, such as over bridge, Multistoried buildings, etc.

Reduction of volume changes and structure failure also, the best method is to stabilization of soil by using fly ash that will reduce volume changes in the soil.

Soil engineering properties are determined by the Atterberg limits, index properties beside liquidity index, and completely different soil properties obtained by laboratory or field tests it acknowledged that the swell-shrinkage characteristics of expansive soils unit closely related to soil plasticity index et al parameters. Several investigate or shave studied empirical relations to estimate the swelling characteristics of expansive soils supported Atterberg limit sand index properties, however the link between swell-shrinkage properties and thus the plasticity index of additives stable expansive soil has not been investigated.

In this research, we will see the effect regarding the stability of soil by using fly ash with a soil sample and make a comparison between the mixed sample and original states of the tested soil. All the tests are performed in the guidance of researchers with the help of lab assistant in the laboratory of geotechnical engineering in Kalinga University, Raipur (C.G.). As resultant by follow standard procedure (IS 2720) we get a positive result regarding stability.

These data shows the stability of soil may increased or not? Which will help to design and plan for some heavy structures in this region? 
Table 1. Data Analysis by Direct Shear Test.

\begin{tabular}{lll}
\hline Test Number & $\begin{array}{l}\text { Normal Stress } \\
\left(\mathbf{k g} / \mathbf{c m}^{2}\right)\end{array}$ & $\begin{array}{l}\text { Shear Stress at Failure } \\
\left(\mathbf{k g} / \mathbf{c m}^{2}\right)\end{array}$ \\
\hline 1 & 0.5 & 0.35 \\
2 & 1.0 & 0.50 \\
3 & 1.5 & 0.72 \\
4 & 2.0 & 0.90 \\
5 & 2.5 & 1.01 \\
\hline
\end{tabular}

Shear Stress $(\tau)=$ Shear Force/Area of Specimen $\left(\mathrm{kg} / \mathrm{cm}^{2}\right)$.

\section{Materials and Methods}

For this test for the stability of the soil, we will use direct shear tests in the laboratory and used black cotton soil and fly ash mixed black cotton soil. Taken five to ten sample sand test with the required standard procedure (As standard IS 2720) but insure that there will be fewer instrumental errors as possible. Through this test analyzed and find the Values of shear stress of the tested soil sample. This is shown in Table 4 and Figure 2.

The standard procedure for direct shear test which has followed by us as follows

1. Prepared a soil specimen of $6 \mathrm{~cm} \times 6 \mathrm{~cm}$ X $2 \mathrm{~cm}$ either from undisturbed soil sample or from compacted and remolded sample of black cotton soil.

2. Fix the higher part of the box to the lower part by the fixing screws. Attach the bottom plate to the lower half.

3. Place a porous stone within the box.

4. For undrained take a look at, place the grid on the stone, keeping the serrations of the grid at right angle to the direction of shear for consolidated undrained and drained tests use the perforated grid in situ of plain grid.

5. Transfer the soil specimen ready in step within the box; weight the box with soil specimen.

6. Place the higher grid, porous stone and loading pad within the order on soil specimen.

7. Place the box within the instrumentality and mount it on loading frame.

8. Bring the upper half of the enclose contact with proving ring assembly. Contact is discovered with proving ring assembly.

9. Fill the instrumentality with soil if saturated. Mount the loading yoke on the ball placed on the loading pad.

10. Mount one dial gauge on the yoke to record the vertical moment and alternative dial gauge on the instrumentality to record the shear moment.

11.Place the weights on the loading yoke to use the conventional stress of intensity $2.5 / \mathrm{cm}^{2}$. Add the load yoke additionally in estimating the conventional stress intensity.

12. Take away the fixing screws from the box and lift slightly the upper half box with the assistance of spacing screws.

13. Modify all the 3 gauges to zero, shear load is applied at a rate of strain, record readings of proving rings dial gauge and vertical and shear movement dial gauges at each half minute.
14. Repeat the above procedure as per required number of sample.

To follow these standard procedure we get detailed shear stress in origin state of soil and mixed soil with fly ash also which can see in Table 1 and Table 4

In this sequence we performed proctor compaction test also in laboratory with standard procedure and getting result which is shown in Table 2 and Table 3 which are detail of moisture content having by soil with $0 \%$ fly ash and $15 \%$ fly ash respectively.

Table 2. Proctor compaction test ( $0 \%$ fly ash).

\begin{tabular}{ll}
\hline Mass of wet soil in the mold $(\mathbf{k g})$ & Moisture content $(\%)$ \\
\hline 1.60 & 10.0 \\
1.70 & 10.7 \\
1.75 & 12.5 \\
1.80 & 14.0 \\
1.85 & 17.2 \\
1.90 & 23.0 \\
\hline
\end{tabular}

Table 3. Proctor compaction test (15\% fly ash).

\begin{tabular}{ll}
\hline Mass of wet soil in the mold $(\mathbf{k g})$ & Moisture content $(\mathbf{\%})$ \\
\hline 1.60 & 8.9 \\
1.70 & 9.2 \\
1.75 & 11.0 \\
1.80 & 13.1 \\
1.85 & 15.2 \\
1.90 & 21.3 \\
\hline
\end{tabular}

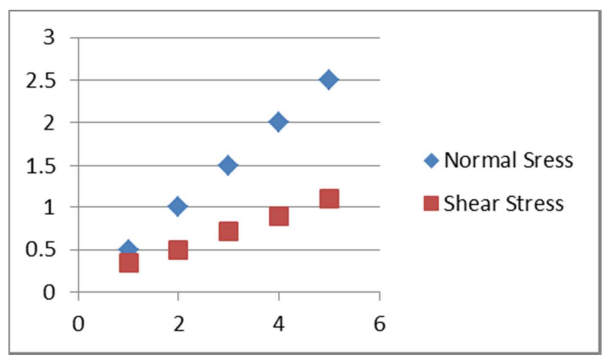

Figure 1. Normal and Shear Stress.

Table 4. Variation in shear stress between original state and fly ash mixed soil.

\begin{tabular}{lll}
\hline $\begin{array}{l}\text { Test Sample } \\
\text { No. }\end{array}$ & $\begin{array}{l}\text { Shear Stress in Original } \\
\text { state }\left(\mathbf{k g} / \mathbf{c m}^{2}\right)\end{array}$ & $\begin{array}{l}\text { Shear Stress in Mixed Soil } \\
\text { with fly } \mathbf{a s h}\left(\mathbf{k g} / \mathbf{c m}^{2}\right)\end{array}$ \\
\hline 1 & 0.35 & 0.358 \\
2 & 0.50 & 0.520 \\
3 & 0.72 & 0.731 \\
4 & 0.90 & 0.910 \\
5 & 1.01 & 1.05 \\
\hline
\end{tabular}

\section{Discussion}

By various researchers conducted laboratory tests and shows results for the application of sandy loam soil after stabilization using additives such as sand, lime, fly ash, etc. This gives the results of stabilization and improvements in the properties of soil with fly ash in the Gujarat region. It is, subsequently, important to moderate the issues uncover by Extensive soils and quit breaking of structures. [2] A few region units as in Gujarat are determined to amazingly far 
reaching soil. top to bottom lab/field preliminaries are allotted by various specialist sand have demonstrated promising outcomes for use of such broad soil once adjustment with added substances like sand, sediment, lime, fly debris, and so forth As debris is unreservedly available, for draws near the region of the Thermal Power Plants, it are frequently utilized for adjustment of extensive soils for various employments. The current paper portrays an examination distributed to imagine the improvements inside the properties of extensive soil with debris in factor rates. [1]

An investigation to evaluate the compaction and unconfined compressive strength of black cotton soil using fly ash. It was found that the peak strength of fine fly ash was $25 \%$ more than course fly ash.

Soil adjustment is one among generally huge for the advancement that is wide utilized regarding street asphalt and establishment development because of It improves the designing properties of soil like strength, volume depend ability and toughness. Inside the blessing examination is to pass judgment on the compaction and unconfined compressive strength of balanced out dark cotton soil abuse fine and coarse debris blends. The portion of fine and coarse debris combinations that is utilized in dark cotton soil differed from 5 to 30 .

Fly debris is a significant mechanical side-effect of coke ignition. [3] In Sudan, there is low utilization of fly debris in development application; it is stored and finished, causing genuine natural issues. In light of its extraordinary accessibility and its low cost, the chance of its utilization should be examined. In the present examination, mud soil was adjustment or the development of sturdy metropolitan streets is explored utilizing fly debris. Geotechnical examination of soil-fly debris blend attributes including physical, mechanical properties, show that there cord properties of mud soil have been improved. The mud Atterberg limits improved and an increment of bearing limit was seen with different debris proportions. It was discovered that the ideal proportion of the fly debris with dirt soil under examination is $15 \mathrm{wt} \%$. As far as possible and versatility record decrease is $54.12 \%, 29.57 \%$ separately while the drenched CBR of the dirt expanded from 3 to $56 \%$. Also follow other researcher's work i.e. [4-15].

In This examination, we utilize fly debris with soil and perform exploratory investigations of different soil tests close to Kalinga University, Raipur, Chhattisgarh, India and Near Mantralaya Bhawan Naya Raipur Chhattisgarh, India. In the wake of Testing I get brings about a positive path method for strength is expanding which can see in Figure 2. This Increment is around 1 to $4 \%$.

\section{Results}

1. It was seen through the trial work that strength of soil expanded up to 1 to $4 \%$ when utilizing fly debris with a dirt example. It was seen that each time security is expanded with fly debris with dark cotton soil in this locale. So this exploration will be successfully valuable to build a substantial structure.

2. Shear pressure will be expanded if utilizing $70 \%$ and $30 \%$ amount of dark cotton soil and Industrial fly debris individually.

3. A little disadvantage is seen that the expense of the development venture is expanded up to $1 \%$ it implies Rs.10000/-Over Rs.10 Lakhs of task. Be that as it may, security is expanded upto 1 to $4 \%$.

4. This work is too time containing, but beneficial for all engineers and contractors also.

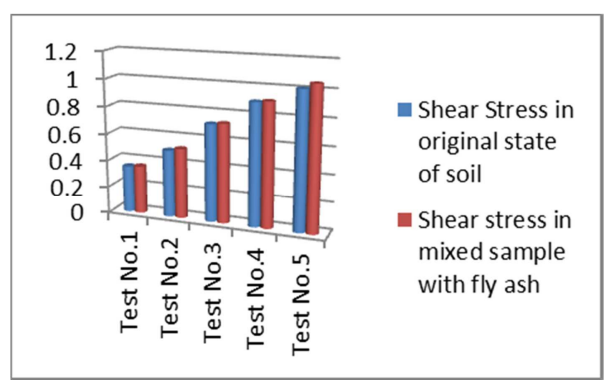

Figure 2. Difference in shear stress in mixed soil with fly ash and original state of soil.

\section{Future Scope}

1. During the design of the foundation a designer should be considered this data for good stability of the structure.

2. The planner should be using this concept before planning for construction in Naya Raipur Region.

3. Should be able to design high-raise building to prepare sector in this region and other heavy structures also such as bridges.

4. Before construction in this area, to stabilization of soil if required the concern (contractor, Engineer etc.) can apply the suitable methods.

\section{Strength and Weakness in This Research}

1. Strength - All the data which are getting by a standard procedure (IS 2720) with various different instruments of geotechnical engineering which will very helpful to all the further researchers and structure developers in this region. This may also be helpful in development of structures related to smart city projects.

2. Drawbacks - In this research black cotton soil is taken up and all the reports and data are based on it. So this research work will be helpful only on that region where black cotton soil will be present not for other types of soil like loamy soil, sandy soil etc.

\section{Conclusion}

From this research work we can see that when we use fly ash with black cotton soil its stability is increased up to $4 \%$ hence we can say that in this region uses of fly ash with black cotton soil will be very effective for the stabilization of structure. 


\section{References}

[1] Gyanen Takhelmayum, Savitha A. L. Krishna Gudi January (2013). "Laboratory study on soil stabilization using fly ash mixtures". ISSN: 2319-5967, Vol. 02, Issue 01.

[2] Prof. Pratik Somaiya, Prof. Yashwant Zala, Prof. Rushikesh Dangar (2013). "Stabilization of expensive soil using fly ash"Conference proceeding on Utilization of fly ash as a building material, Surat, Gujarat, India.

[3] Dr. Afaf Ghais Abadi Ahmed, (2014). "Fly ash utilization in soil stabilization international conference on civil, Biological \& Environmental Engineering (CBEE-2014), Istanbul (Turkey).

[4] A. Riehl, F. Elsass, J. Duplay, F. Huber, M. Trutmann. (2010). "Changes in soil properties in a fluvisol (Calcaric) amended with coal fly ash" Geoderma, Vol. 155, Issue 1-2. Pages 67-74.

[5] Pankaj R. Modak, Prakash B. Nangare, Sanjay D. Nagrale, Ravindra D. Nalawade, Vivek S. Chavhan. (2012). "Stabilization of black cotton soil using Admixtures", IJEIT, Vol. 1, Issue 5, May.

[6] MarAstruptina Vitkova, Jiri Hyks, Vojtech Ettler, Thomas. (2013). "Stability and leaching of cobalts melter fly ash" Applied Geochemistry, Vol. 29, Pages 117-125.

[7] Sumio Horiuchi, Masato Kawaguchi, Kazuya Yasuhara (2000). "Effective use of fly ash slurry as fill materials" Journal of Hazardous materials, Vol. 76, Issue 2-3, Pages 301-337.

[8] Ravi Kumar Sharma, Babita Singh (2013). "Modification of clayey soil using fly ash" IJRET, eISSN: 2319-1163, pISSN: 2321-7308, Vol. 10, Issue-10.

[9] Lovedeep Singh Sambyal, Neeraj Sharma (2018). "Utilizing Fly Ash and Alccofine for Efficient Soil Stabilization" IJSER, ISSN: 2229-5518, Vol. 9, Issue 3.

[10] Wajid ali Butt (2018). "An Innovative Technique of Stabilization of Soil for Pavements Using Fly Ash and Steel Slag “IJSR, ISSN: 2319-7064, Vol. 7, Issue 8.

[11] S. Lakshman Teja, S. Shraavan Kumar Dr. S. Needhidasan (2018). "A Review and Study on Stabilization of Expansive soil using brick dust" International Journal of Pure and Applied Mathematics, ISSN: 1314-3395, Vol-119, No. 17.

[12] Md. Omar Faruk, Mohammad Shariful Islam, Mohammad Ziaul Hoque and Marzia Ashraf Shorno (2019). "Stabilization of dispersive soil by using fly ash" International Conference on Disaster Risk Management, Dhaka, January 12-14, 2019.

[13] Abhishek Kiran Bhamre (2019). "Stabilization of Expansive Soil by Industrial Solid Wastes by using Fly ash and Corex Slag"IJERT, ISSN: 2278-0181, Vol. 8, Issue 7.

[14] Shrawan Kumar Yadav, Indra Prasad Acharya (2019)."Stabilization of Kalimati Soil Using Fly Ash" IOE Graduate Conference, 2019-Winter, ISSN: 2350-8914. Vol. 7.

[15] Simit Sarngal, Anoop Sharma (2019), "Experimental study on stabilisation of clayey soil by using Fly Ash and Sisal fiber" IJETT, Volume-67 Issue-10. 